3. Petr Karel. Srovnávací reklama v právu EU a v ČR. Právní rozhledy. 1996. - № 7. - st. 317

4. Булеца С.Б. Роль інформації та реклами в медичній діяльності. Держава і право: Збірник наукових праць. Юридичні і політичні науки. - Вип. 48. - 2010. - С. 357-365.

DOI: http://doi.org/10.31617/k.knute.2019-03-19.24

\title{
КОМУНІКАЦІЙНА СТРАТЕГІЯ БРЕНДУ В ЦИФРОВОМУ
} СУСПІЛЬСТВІ

\author{
Буряк Р.В. \\ студент магістратури \\ кафедра журналістики та реклами \\ Київський національний торговельно-економічний університет, \\ Україна
}

Ключові слова: інформаційне суспільство, циифрові комунікації, маркетинг, брендинг, комунікаційна стратегія, соціальні медіа, електронна комериія, Інтернет.

Keywords: information society, digital communications, marketing, branding, communication strategy, social media, e-commerce, Internet.

У сучасному світі інформаційне суспільство поступово еволюціонувало в цифрове, остаточно перевівши комунікації у віртуальний простір глобальної мережі Інтернет.

Інформаційне суспільство (IC) - це постіндустріальний етап розвитку суспільства, що характеризується провідною роллю інформації в усіх сферах економічного та соціального життя людини. 3 одного боку, інформація і знання розглядаються в якості рушійної сили економіки. П. Дракер (Peter F. Drucker) називає таке суспільство «суспільством знання» [2]. Таке ж трактування можна знайти в роботах Д. Белла (Daniel Bell) [3], A. Тоффлера (Alvin Toffler) [6]. 3 іншого боку, інформаційні технології закладаються в основу функціонування IC. До такого підходу схиляється Б. Гейтс (William Henry Gates), в книзі «Дорога в майбутнє» [7] і Дон Тапскотт (Donald Tapscott), який написав більше десятка робіт про покоління «працівників знання» [4], «цифровий капітал» [5] та «вікіноміку» [9].

Подальший розвиток наукової думки в умовах бурхливого зростання інформаційних технологій призвів до появи нового терміна «цифрове суспільство». Це сталося в 1996 році після виходу в світ книги 
Дона Тапскота «Електронно-цифрове суспільство: Плюси і мінуси епохи мережевого інтелекту» [10]. Автор сформулював основні ознаки нового суспільства: орієнтація на знання, цифрова форма представлення об'єктів, віртуалізація виробництва, інноваційна природа технологічних процесів, інтеграція і конвергенція систем всіх рівнів, усунення посередників і спрощення ланцюжка «виробник - споживач», динамізм і глобалізація комунікацій. Д. Тапскот виділив п'ять базових елементів, на основі яких функціонує і розвивається цифрове суспільство [10]:

1. «Ефективна особистість» - індивід, який володіє сучасним комп'ютером, підключеним до глобальної мережі Інтернет;

2. «Високопродуктивний колектив» - робоча група співробітників, яка використовує цифрові технології для виконання своїх завдань;

3. «Інтегроване підприємство» - компанія, в якій всі бізнеспроцеси організовані в цифровому інформаційному середовищі;

4. «Розширене підприємство» - компанія 3 розгалуженою мережею філій, об'єднаних розподіленою комп'ютерною мережею;

5. «Ділова активність в міжмережевому середовищі» - глобальне цифрове співтовариство.

Дослідження, проведені групою маркетологів під керівництвом Девіда Корта, показали, що «сьогоднішні покупці не просто звужують сферу пошуку, а йдуть по більш складній траєкторії, залишаючи собі на кожному з етапів більше варіантів для вибору» [1].

Сприйняття бренду формується у споживача в точках дотику, таких як рекламні оголошення, новини, розмови з сім'єю і друзями, власний досвід використання продукту. У цифровому суспільстві кількість точок дотику збільшилася, вони стали якісно іншими. При цьому великий обсяг інформації надходить 3 каналів, які власники бренду не контролюють.

У моделі Корта виділено чотири стадії [1]:

1. Огляд пропозицій різних брендів.

2. Активна оцінка за допомогою пошуку інформації у знайомих, в оглядах продукції та ін.

3. Купівля.

4. Використання, рекомендації та формування зв'язку на основі довіри до бренду.

Комунікаційна стратегія бренду - це великомасштабне планування просування бренду для досягнення заданих цілей. Вона базується на позиціонуванні бренду і вирішує завдання комунікації 3 конкретними групами цільових аудиторій. Цілями стратегії можуть бути створення певного іміджу бренду, підтримку і посилення лояльності споживача по відношенню до торгової марки в цілому і іiі окремих продуктів. 
Результатом розробки комунікаційної стратегії $\epsilon$ формування плану (тактичних етапів) маркетингових комунікацій, що реалізуються комплексно відповідно до завдань кожного етапу.

Сьогодні комунікаційна стратегія бренду соціалізувалася і стала більш орієнтованою на персональні інтерактивні контакти зі споживачем. Сучасний практичний брендинг грунтується на людиноподібності і гуманізації брендів. Такі типові характеристики, як якість i надійність, повинні бути присутніми в бренді з самого початку. Вони вже не $є$ показниками вибору споживачів. Цифрові комунікації надали брендам можливість встановити міцний зв'язок зі споживачем, долучити до загальних справ через ідеї і цінності, близькі споживачеві. У даний час в основі побудови бренду лежить ідея про те, що бренд повинен належати не виробнику, а споживачеві. Багато брендів добровільно передають частину своїх повноважень споживачеві: проведення опитувань, вивчення громадської думки про продукт в соціальних мережах. Оскільки дієвий контроль над споживчими комунікаціями в цифровому суспільстві практично не можливий, брендам залишається активно включитися в комунікацію на правах партнера, проповідуючи свої ідеї і цінності, емоційні і соціальні вигоди.

Великі бренди одними 3 перших стали вирішувати стратегічні довгострокові маркетингові завдання через соціальні медіа, які забезпечують велике охоплення, інтерактивність і використання відразу декількох майданчиків комунікації.

Соціальні медіа забезпечують дві основні функції: sharing (ділитися контентом) i response (відношення до контенту - коментарі та позначки Like). Додатково можлива допоміжна функція following (слідувати) - стежити за тим, чим діляться інші користувачі. Таким чином, існує ефективний механізм, за допомогою якого можливі комунікації між користувачами при обміні контентом, який створив бренд. Також можна додавати бренд в друзі.

Для вирішення комунікаційних завдань бренду соціальні медіа представляють дуже цінний канал:

- відсутні тимчасові обмеження (доступні 24 години);

- володіють швидкою реакцією на будь-яке повідомлення бренду (відповідь представника на коментар користувача за короткий часовий інтервал);

- забезпечують високу швидкість поширення контенту без будьяких географічних обмежень.

Мартін Ліндстром [8] писав, що незабаром буде розвиватися «реаліті-брендинг», близький до рекламних прийомів «product placement» i вже розвивається «situational placement», коли навколо бренду створюється ціла історія. Наприклад, казуальна гра 
«SimCityMcDonald's». Можна побудувати багато об'єктів, наповнити їх інтер'єром, але всі вони будуть мати «відбиток» бренду McDonald's.

У цифровому суспільстві бренди отримали необмежені можливості встановлення близького контакту зі споживачем. Персоналізація комунікацій і відсутність тимчасових обмежень зробили більш органічною можливість присутності бренду в житті людини. У розробці комунікаційної стратегії бренду потрібно не забувати про складну траєкторію, по якій йде споживач в процесі вибору продукту, $\mathrm{i}$ ретельно планувати взаємодію в точках дотику. У сучасному маркетингу споживач став повноправним партнером бренду. Саме ця ідея і повинна бути в основі запланованих споживчих комунікацій.

\section{Список використаних джерел}

1. David Court, Dave Elzinga, Susan Mulder, and Ole Jørgen Vetvik. The consumer decision journey [Електронний ресурс]. - Режим доступу : https://www.mckinsey.com/business-functions/marketing-and-sales/ourinsights/the-consumer-decision-journey (дата звернення: 24.02.2019).

2. Drucker P.F. Post-Capitalist Society / P.F. Drucker. - N.Y. : Pantheon, 1993. - p. 93

3. Bell D.. The Coming of Post'Industrial Society: A Venture in Social Forecasting / D. Bell. - Harmondsworth : Penguin, 1973. - p. 84

4. Tapscott D. Growing Up Digital: The Rise of the Net Generation / Don Tapscott. - N.Y. : McGraw-Hill, 1998. - p. 39

5. Tapscott D. Digital Capital: Harnessing the Power of BusinessWebs / Don Tapscott, David Ticoll, Alex Lowy. - Boston : Harvard Business School Press Book, 2000. - p. 176

6. Toffler A. Powershift: Knowledge, Wealth, and Violence at the Edge of the 21st Century /A. Toffler. - N.Y. : Bantam, 1990. - 83 p.

7. Гейтс Б. Дорога в будущее / Билл Гейтс. - М.: Рус. ред., 1996. - 65 с.

8. Линдстром М. Детский брендинг / Мартин Линдстром, Патриция Б. Сейболд / пер.санг. С. Варламова. - СПб. : Нева, 2004. - 127 с.

9. Тапскотт Д., Уильямс Э. Д. Викиномика. Как массовое сотрудничество изменяет все/ Дон Тапскотт, Энтони Д. Уильямс / пер. с англ. П. Миронова, Г. Василенко. - М.: BestBusinessBooks, 2009. $92 \mathrm{c}$.

10. Тапскотт Д. Электронно-цифровое общество: Плюсы и минусы епохи сетевого интеллекта/ Дон Тапскотт /пер.санг. И. Дубинского. Под ред. Сергея Писарева. /Киев: INT Пресс; - М.: Релф бук, 1999. $136 \mathrm{c.}$ 